\title{
Alojzij Geržinič, Od Save do Srebrne reke
}

Mladika, Trst, 2015

\section{Pavle Borštnik, Moj čas}

Mladika, Trst, 2016

Urednik nove knjižne zbirke tržaške založbe Mladika Ivo Jevnikar na notranjem ovitku Geržiničeve knjige Od Save do Srebrne reke piše: »S spomini prof. Alojzija Geržiniča založba Mladika začenja novo zbirko Zapisi iz zdomstva, posvečeno knjigam, ki so jih napisali Slovenci po svetu. S tem želi še bolj načrtno izpolnjevati eno izmed poslanstev, ki sta si jih od začetka zastavili revija, nato pa še založba Mladika. Gre za dialog in povezovanje rojakov ter utrjevanje skupnega slovenskega prostora.«Praviloma naj bi vsako leto izšel po en knjižni naslov.

Naslov zbirke je založba povzela po istoimenskem naslovu knjige, ki jo je leta 1977 pri Slovenski kulturni akciji (SKA) v Buenos Airesu izdal France Papež. Žal je tudi ta knjiga doživela podobno usodo kot večina knjig, ki so v prejšnji skupni državi izšle v zdomstvu - neopazno je šla mimo bralcev. O njej se v domovini ni ne pisalo ne govorilo. Na srečo je po osamosvojitvi Slovenije doživela ponatis v zbirki Paradigme, ki jo je leta 1992 izdala Nova revija, spremno besedo k novi izdaji pa je napisal Marko Jenšterle. A tudi ta izdaja ni mogla popraviti zamujenega. Papeževi »zapisi so nastali kot odmev vživljanja v slovensko zdomsko problematiko; so odziv na zgodovinska in človeška vprašanja povojnega emigranta. Niso samo kronika - oblikovani so v literarni, včasih vizijski in poetični besedi, drugekrati prikazujejo gola zgodovinska dejstva. Morda bo knjiga tako lažje našla pot do bralca, ki se zanima za zdomske stvari, a jih išče v bolj pripovedni in občuteni obliki. V zapisih je zdomstvo razpeto od intimnega osebnega do širše zgodovinskega; zakoreninjeno je v preteklosti in morda bi se tu lahko še marsikaj dodalo in izpopolnilo." France Papež je namreč tudi »avtor» termina »zdomstvo = biti zdoma».

V svoji kritični analizi zdomskega življenja je posebno poglavje namenil prav knjigam: »Mislim, da je bila poleg svobodnega ustvarjanja in duhovnega nemira takrat najbolj poudarjena važnost, ki jo zavzema za nas in za vsakogar knjiga. Knjiga je vez med človekom in človekom, se pravi, vez med tabo in mano, vez med nami in vami. [...] V zdomstvu je knjiga osnovno sredstvo za ohranjanje slovenske narodne zavesti. Knjiga nas človeško in narodnostno osvešča in ohranja, obenem pa nas vodi po zemljah, v katerih bi se brez nje že davno izgubili. [...] Za nas v zdomstvu je knjiga še posebej to: skrinja slovenstva, najdražje izročilo za na pot, tolažba v trenutku samote, spremljevalka po kamnitih, peščenih poteh novega kontinenta; zapisi poti navzgor in poti navzdol; bukve, kjer stoje besede davnih dni« (str. 37-38).

Nova knjižna zbirka je prišla kot naročena. Zadnjih nekaj let smo priča usihanju »slovenskega čudeža v Argentini«, pa tudi asimilacija je naredila svoje. Ob tem pa vse pogosteje umirajo predstavniki prve in sedaj že tudi druge generacije slovenske politične emigracije (SPE). Pred nedavnim se je nenadoma poslovila predsednica SKA, dr. Katica Cukjati (1949-2016). Do sedaj sta v zbirki izšli dve knjigi spominov, obe sta napisala predstavnika prve generacije SPE, ki sta na lastni koži doživela begunsko usodo. Ta se je začela ob koncu vojne, maja 1945, nadaljevala v italijanskih begunskih taboriščih, nato pa sta se njuni poti razšli. Dr. Alojzij Geržinič (1915-2008) se je priključil večinski izselitvi v Argentino, Pavle Borštnik (1925) pa se je odločil za preselitev v ZDA. Oba sta bila ves čas aktivna člana zdomske skupnosti. 
Spominski zapisi uglednega slavista, glasbenika, publicista, urednika in šolnika nam na zanimiv način predočijo njegovo lastno življenjsko pot in ob tem predstavijo tudi nemirni čas predvojne, medvojne in povojne slovenske družbe. Njegova pripoved je izredno zanimiva in še zlasti preseneča dejstvo, da je v teh zapisih tako natančen in se živo spominja še tako neznatnih dogodkov. Zato ima knjiga tudi veliko dokumentarno vrednost. Knjiga je sestavljena iz dveh delov, ki sta ločena tako kronološko kot po času pisanja. Prvi del spominov nosi naslov Dni mojih mlajša polovica in zajema prvo tretjino njegovega življenja: otroštvo, šolsko dobo, prvo zaposlitev, ideološke opredelitve in priključitev primorskim domobrancem. V ta del je avtor vključil tudi dve svoji zgodnejši deli: Pouk v materinščini - da ali ne? (Sij, Buenos Aires 1972) in Boj za slovensko šolstvo na Primorskem: Za delovanja dr. Srečka Baraga pri ZVU (Buenos Aires: SKA, 1983). Obe knjigi je avtor napisal na podlagi svojega dnevnika.

Drugi (skromnejši) del, ki nosi naslov Dogajanja in dognanja, pa nas seznani z njegovim odhodom iz Trsta in življenje v begunskih taboriščih v južni Italiji. Med prvimi se je nato odločil za preselitev v Argentino in se takoj aktivno vključil v politično in kulturno življenje SPE. Zlasti so zanimivi njegovi kritični pogledi na dogajanje v tamkajšnji slovenski skupnosti. S svojo načelno držo in nepopustljivostjo je aktivno sodeloval pri sporu v SKA in se priključil bolj radikalni skupini, ki je nato začela izdajati svojo publikacijo Sij slovenske svobode. Škoda, da avtor svoje pripovedi ni dopolnil tudi z bolj podrobnim opisom političnega dogajanja znotraj SPE, ampak se je osredotočil le na njeno kulturno delovanje. Na koncu knjige je dodana tudi obsežna avtorjeva bibliografija. Zelo dragoceni so podatki o njegovih psevdonimih oz. kraticah, ki jih je uporabljal pri svojem pisanju in ki bodo v veliko pomoč prihodnjim raziskovalcem zdomske problematike.

Tudi druga knjiga je spominskega značaja in nam predstavlja izredno pestro življenje časnikarja, pesnika, publicista, glasbenika in javnega delavca Pavleta Borštnika, ki je bil v letih 1970-1994 zaposlen v Washingtonu pri državnem radiu Glas Amerike. Ker gre za izredno obsežno (623 str.) in podrobno pisanje, je še kako dobrodošlo osebno kazalo na koncu knjige. Spomini so sicer zasnovani kronološko, vendar se nekateri pomembni dogodki v pripovedi večkrat ponovijo, a vsakič iz drugega zornega kota. Knjiga je sestavljena iz štirih poglavij: 1. del - Mladost ... gozdovi ... taborišča; 2. del - V Ameriko; 3. del - Washingtonska leta; sklepno poglavje - Obračun. Avtor, ki zna zelo spretno »sukati pero«, je v knjigi združil pravzaprav dva žanra: avtobiografijo in obsežna razmišljanja o dogodkih, ki so usodno vplivali na njegovo generacijo. Kljub mladosti so bile njegove odločitve trezne in preudarne. Pri pisanju se ne izogne tudi nekaterim bolj bolečim temam in odločitvam, a jih skuša nekako razumeti/pojasniti, ker so se večinoma zgodile v vojnem času in kot posledica pomanjkljivih informacij.

Tudi Borštnikovi spomini nam odkrito spregovorijo o predvojnem ločevanju duhov, kar se je med samo vojno samo še poglobilo in na koncu privedlo do bratomorne vojne. Sam se je priključil četnikom in se z njimi ob koncu vojne tudi umaknil preko Soče in nato nekaj let preživel v vojaških taboriščih v Italiji in Nemčiji. Srečno naključje ga je pripeljalo v Cleveland, kjer je takoj opazil velika razhajanja med predvojno in povojno emigracijo. Še bolj boleče pa je doživljal spore znotraj same SPE, ki so na koncu privedli do popolne ločitve in nastanka dveh ločenih borčevskih organizacij, ki sta se zbirali okoli glasil Vestnik in Tabor.

Kar obsežen del knjige opisuje njegovo delo pri radiu Glas Amerike (slovenska sekcija), kjer prav tako ni manjkalo razhajanj (nagajanj) med predstavniki različnih jugoslovanskih 
narodov. Posebna odlika knjige je njen lep jezik, ki niti malo ne kaže na to, da je avtor zapustil domovino že davnega leta 1945. Izredno lepi so njegovi opisi narave, ki jo je kot lirik doživljal še posebej občuteno. Ne manjka pa v knjigi tudi šaljivih in hudomušnih prizorov, zlasti v času njegove mladosti. V Predgovoru nam Pavle Borštnik tudi razkrije namen/ način svojega pisanja: »Pot, po kateri sem hodil med vojno in revolucijo na Slovenskem, je le nekoliko drugačna od drugih, bolj poznanih (in bolj tragičnih), čeprav sem s prijatelji hodil po njej v istem mladostnem zanosu in $\mathrm{z}$ enakimi upanji kakor kdorkoli drug, ki je $\mathrm{v}$ tistih težkih časih hrepenel po vsem, kar sta nam vojna in revolucija za vselej iztrgala in src in duš. Usojeno mi je bilo, da sem obstal. S tem sem prevzel dolg pričevalca o ljudeh in dogodkih tistega časa. Dogodki so šli včasih mimo nas, včasih preko nas, ljudje pa so bili moji bratje, na eni in drugi strani. Desetletja že počivajo v naročju domače zemlje, kjer ni ne sovraštva ne zlobe, samo mir, ljubezen in - odpuščanje ... Nanje sem mislil pri pisanju teh zapiskov« (Predgovor, str. 7).

Kot tretji zvezek nove zbirke naj bi v letu 2017 izšli spomini družine Mihevc iz okolice Cerknice, ki se je ob koncu vojne pridružila množici beguncev, ki so se umaknili na Koroško. En brat in sestra sta se odločila za izselitev v Kanado, drugi brat (domobranec) pa je bil vrnjen v Jugoslavijo in srečno preživel bivanje v taborišču Teharje.

Rozina Švent 